HEALTH RISK ANALYSIS RELATED

TO ORGANIZATIONAL TASKS IN PUBLIC HEALTHCARE

UDC 616.348-002.44-036.17-079.3: 575.174.015.3

DOI: $10.21668 /$ health.risk/2019.2.16.eng

\title{
UNFAVORABLE CLINIC COURSE OF ULCERATIVE COLITIS: RISK ASSESSMENT WITH DETERMINING GENE POLYMORPHISM OF TUMOR NECROSIS FACTOR ALPHA
}

\author{
Y.I. Tretyakova ${ }^{1}$, A.P. Shchekotova ${ }^{1}$, I.A. Bulatova ${ }^{1}$, A.V. Krivtsov ${ }^{2}$ \\ ${ }^{1}$ Perm State Medical University named after Academician E.A. Wagner, 26 Petropavlovskaya Str., Perm, 614000, \\ Russian Federation \\ ${ }^{2}$ Federal Scientific Center for Medical and Preventive Health Risk Management Technologies, 82 Monastyrskaya \\ Str., Perm, 614045, Russian Federation
}

The research goal was to assess functional significance that belonged to TNF- $\alpha$ gene polymorphism in the region 308G/A (rs1800629) in ulcerative colitis development.

The authors examined 70 patients with ulcerative colitis when the disease was in its active phase and 50 healthy donors. They focused on TNF- $\alpha$ concentration in blood serum and TNF- $\alpha$ gene polymorphism in the region $-308 G / A$.

It was detected that TNF- $\alpha$ level was authentically higher in patients who suffered from grave ulcerative colitis and had high endoscopic activity than in people with low endoscopic activity and milder forms of the disease. It allows to apply these tests as additional non-invasive markers to assess apparent damages done to the mucous tunic in the large intestine in a patient suffering from ulcerative colitis. Frequency of allele variations in TNF- $\alpha$ gene -308G/A (rs1800629) was assessed; the assessment revealed that unfavorable homozygote AA significantly more frequently occurred in patients with ulcerative colitis than in donors. Besides, ulcerative colitis might be accompanied with different endoscopic activity; the major allele $G$ and the allele pair GG significantly more frequently occurred among patients with mild and average disease attack and 1-2 degree of endoscopic activity than among patients with 3-4 degree of endoscopic activity and grave ulcerative colitis $\left(\chi^{2}=14.19 ; p=0.000\right)$. The authors also detected a mutant allele $A$ and the unfavorable homozygote AA associated with grave progressive ulcerative colitis. Mutant allele occurrence causes 5 times higher risk that a patient will have to face the disease in its grave form (OR 5.03; CI 12.07-12.21).

Therefore, risks related to unfavorable clinical course of ulcerative colitis with frequent recurrences and fast progressing are associated with the allele A of TNF- $\alpha$ gene in the region -308G/A. It should be taken into account when making forecasts on the clinical course of the disease and choosing treatment strategies.

Key words: damages to the mucous tunic in the large intestine, ulcerative colitis, TNF- $\alpha$, gene polymorphism, assessment of gene variations occurrence, TNF- $\alpha$, degree of attack severity, endoscopic activity.

Ulcerative colitis (UC) is a chronic disease in the colon that involves immune inflammation in its mucous tunic, usually without any granulomas detected with biopsy $[1,2]$. Undoubtedly, diagnostics, treatment, and prevention of UC are vital issues nowadays. It is confirmed with ab- sence of complete data on the disease etiology, incidence growth among workable population, recurrences, development of life-threatening complications, necessity to perform long-term, often lifelong and expensive therapy, and unfavorable medical and social forecasts [3-5].

(c) Tretyakova Y.I., Shchekotova A.P., Bulatova I.A., Krivtsov A.V., 2019

Yuliya I. Tretyakova - Candidate of Medical Sciences, Associate Professor at the Polyclinic Therapy Department (e-mail: tretyakovayi@gmail.com; tel.: +7 (342) 217-10-31; ORCID: http://orcid.org/0000-0002-7411-6204).

Alevtina P. Shchekotova - Doctor of Medical Sciences, Professor, head of the Clinical Laboratory Diagnostics Department (e-mail: al_shchekotova@mail.ru; tel.: +7 (342) 217-10-31; ORCID: http://orcid.org/0000-0003-0298-2928).

Irina A. Bulatova - Doctor of Medical Sciences, Professor at the Clinical Laboratory Diagnostics Department (e-mail: bula.1977@mail.ru; tel.:+7 (342) 217-10-31; ORCID: http://orcid.org/0000-0002-7802-4796).

Aleksandr V. Krivtsov - Candidate of Medical Sciences, Head of Immune Genetics Laboratory (e-mail: krivtsov@fcrisk.ru; tel.: +7 (342) 236-86-99; ORCID: https://orcid.org/0000-0001-7986-0326). 
Immune-inflammatory process with cytokines imbalance is a leading mechanism in UC development and progression [6, 7]. Tumor necrosis factor-alpha (TNF- $\alpha$ ) is the strongest anti-inflammatory cytokine that participates in UC pathogenesis [8]. It is produced by macrophages in the colon and can directly damage its mucous barriers causing inflammatory changes $[9,10]$. Bacterial lypopolysaccharides are considered to be a significant TNF- $\alpha$ inductors; when UC occurs, they can be found in great quantities in the colon lumen. Research revealed that that $77.8 \%$ patients suffering from UC had increased TNF- $\alpha$ level in the colon mucous tunic in the acute phase of the disease [11].

$\mathrm{UC}$ is a disease with genetic heterogenic complex predisposition [12]. Recently a lot of works have been accomplished that revealed correlations between variants of alleles in genes of regulatory inflammation molecules, relevant proteins production, and predisposition to this or that disease. Knowing their role in pathogenesis of many diseases allows, on the one hand, to predict risks related to pathology development or how grave this pathology is going to be; on the other hand, to make a choice on a specific therapy for a concrete patient [13]. There is active search for genes that are responsible for predisposition to UC [14]. When $T N F-\alpha$ gene polymorphism was examined in patients with UC in comparison with healthy people, the highest statistically significant changes were detected in -308 G/A position $[15,16]$. As per data obtained by F. Wang [et al.] there were no statistically significant discrepancies in frequency of allele variations in $T N F-\alpha-308 \mathrm{G} / \mathrm{A}$ gene between patients with UC and healthy people, either among Europeans, or Asians. However, researchers revealed GA and GA + AA genotype prevalence over GG one among Asians [17]. According to some other data, frequency of $\mathrm{A}$ and $\mathrm{G}$ genotypes and alleles in $T N F-\alpha$ gene (-G308A) among patients with UC didn't have any discrepancies from that detected among population in general $[18,19]$.

Therefore, literature data on assessing a contribution made by $T N F-\alpha-308$ G/A gene polymorphism into immune inflammatory development in the colon in case of UC are rather controversial. There are not enough data on a correlation between polymorphism of the said gene and UC attack gravity and endoscopic changes; thus, a basic trend of our research was identified.

Our research goal was to assess functional significance of $T N F-\alpha$ gene polymorphism in -308G/A (rs1800629) region in UC progression (on the example of patients living in Perm region).

Data and methods. We examined 70 patients with UC with the disease being in its active inflammatory phase. Average age amounted to $36.21 \pm 11.69,34$ were males, and 36 , females ( $48 \%$ and $52 \%$ respectively). Duration of the disease was on average equal to $7.24 \pm 6.56$ years. Patients were examined at gastroenterology and surgical departments in the Clinical Medical-Sanitary Hospital No. 1 and City Clinical Hospital No. 2 (Perm). UC was diagnosed on the basis of clinical recommendations on diagnostics and treatment of patients with UC [1]. We assessed endoscopic activity (EA) and clinical and endoscopic activity indexes (CAI and EAI). A control group was made up of 50 practically healthy people and was comparable with the test group as per age and sex.

We measured TNF- $\alpha$ concentration in blood serum of all the examined people with ELISA test applying ELISA test kits produced by "Vektor Best" LLC (Novosibirsk); results were registered with "Stat-Fax" photometer (The USA). To detect single nucleotide polymorphisms of TNF- $\alpha$ gene in region -308G/A in patients with UC and healthy people, we applied PCR in real time mode; whole DNA was extracted out of whole venous blood that had been preliminary stabilized with ethylenediaminetetracetic acid with "DNA-Sorb-V" set ("Inter Lab Service" LLC, Moscow). We examined polymorphism of $-308 \mathrm{G} / \mathrm{A}$ in $T N F-\alpha$ gene with Realtime "CFX-96" amplifier ("Bio-Rad Laboratories, Inc.", the USA) applying allele-specific PCR "SNP-Screen" ("Syntol" LLC, Moscow) with product detection in real time mode. 
All the obtained results were statistically processed with Statistica 7.0 (Stat Soft). To describe obtained quantitative signs, we presented data as medians $(\mathrm{Me})$ and 25 th and 75 th percentile. To assess significance of discrepancies between independent groups, we applied non-parametric Mann-Whitney test. We quantitatively assessed a linear correlation with Spearman correlation coefficient (r). We applied $\chi^{2}$ technique to describe ratios of genotypes and alleles frequencies in the examined genes and determined odds ratio (OR) as a ratio of a probability that an event occurs to a probability that it doesn't occur. A dependence between examined qualitative signs was determined as per contingency tables (cross tabulation) ${ }^{1}$. We measured how strong a correlation between signs was with Pearson's contingency coefficient (Ki). Discrepancies between samplings were considered to be authentic at $\mathrm{p}<0.05$.

Results and discussion. Our research allowed us to reveal that there was a significant increase in TNF- $\alpha$ concentration in blood serum of patients with UC in its active phase against practically healthy people $(3.38(0.85-4.90)$ and $0.00(0.00-0.00) \mathrm{pg} / \mathrm{ml}$ respectively; $\mathrm{p}=0.02)$, which was well in line with literature data $[6,9,11]$. Values of the factor were higher than average in $86.2 \%$ (62 people) patients against reference values. Therefore, most patients with UC during the disease attack had TNF- $\alpha$ anti-inflammatory cytokine content in blood serum that was several times higher than reference values and it proved that the nosology involved an apparent immune-inflammatory component.

Correlation analysis revealed a significant strong direct correlation between TNF- $\alpha$ contents in blood serum and UC attack gravity $(\mathrm{r}=0.77 ; \mathrm{p}=0.000)$, CAI $(\mathrm{r}=0.4$; $\mathrm{p}=0.04)$, EAI $(\mathrm{r}=0.31 ; \mathrm{p}=0.01)$, and duration of erosive-ulcerative processes in the colon $(r=0.3 ; p=0.04)$. That is, TNF- $\alpha$ adequately assesses prevalence and intensity of

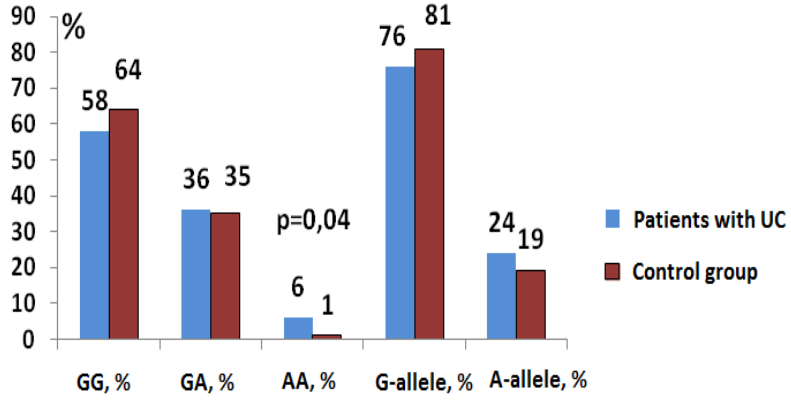

Figure 1. Frequency of detected allele variants in $T N F$ - $\alpha$ gene, $-308 \mathrm{G} / \mathrm{A}$ (rs1800629) region, among examined healthy people and patients with UC. Y-axis shows a number of patients given in $\%$. $\mathrm{X}$-axis shows genotypes and alleles in $T N F-\alpha$ gene, (rs1800629) section

inflammation in the colon. Assessment of TNF- $\alpha$ contents in blood serum can be applied to stratify UC attack gravity, determine endoscopic activity, and to discuss therapy adjustments as it was confirmed by some researchers $[8,10,11]$.

We examined what polymorphism genotypes and alleles prevailed in region rs 1800629 of $T N F-\alpha$ gene among patients with UC and healthy people in Perm region and revealed that GG genotype prevailed (Figure 1).

We didn't detect any authentic discrepancies in frequency of protective allele $\mathrm{G}$ (76.43\% and $81.48 \%$ respectively; $\chi 2=1.16$; $\mathrm{p}=0.28 ; \quad \mathrm{OR}=0.74$ ) and minor allele $\mathrm{A}$ $(23.57 \%$ and $18.52 \%$ respectively; $\chi 2=1.16$; $\mathrm{p}=0.28 ; \mathrm{OR}=1.36)$ prevalence in $T N F-\alpha$ gene, $-308 \mathrm{G} / \mathrm{A}$ region, in the examined groups, which was consistent with other research data $[17,18]$. However, unfavorable homozygote AA was significantly more frequently detected among patients with UC than among practically healthy people $(5.71 \%$ and $1.23 \%$ respectively; $\chi 2=2.35 ; \quad \mathrm{p}=0.04$; $\mathrm{OR}=4.85$ ) (Figure 1). Therefore, if a person has homozygote AA in TNF- $\alpha$ gene (rs1800629), it can be considered a sign that he or she is genetically predisposed to UC.

To perform comparative analysis of TNF- $\alpha$ level and to assess functional significance that

\footnotetext{
${ }^{1}$ Shelud'ko V.S., Poluzhnaya M.Ya Theoretical aspects of medical statistics: a procedure and recommendations. - Perm, 2001. -36 p.
} 
Table 1

TNF- $\alpha$ level and frequency of allele variants occurrence for $T N F-\alpha$ gene in $-308 \mathrm{G} / \mathrm{A}$ (rs1800629) region in patients with UC depending on attack gravity (AG) and EA degree

\begin{tabular}{|r|c|c|c|c|c|}
\hline \multirow{2}{*}{ Factor/genotype/alleles } & \multicolumn{2}{|c|}{$\begin{array}{c}\text { UC, } \mathrm{n}=70 \\
\text { Attack gravity (1-2) } \\
\text { and I-II degree EA; } \\
(\mathrm{n}=37) ; \% \pm \mathrm{m}\end{array}$} & $\begin{array}{c}\text { Attack gravity (3) } \\
\text { and III-IV degree EA; } \\
(\mathrm{n}=33) ; \% \pm \mathrm{m}\end{array}$ & \multirow{2}{*}{ OR(95\%CI) } \\
\hline \multirow{2}{*}{ TNF- $\alpha, \mathrm{pg} / \mathrm{ml}$} & $0.90(0.20-2.55)$ & $8.70(7.10-12.00)$ & - & $\begin{array}{c}0.000 \\
0\end{array}$ \\
\hline \multirow{2}{*}{$T N F-\alpha$} & GG. \% & $78.38 \pm 6.77$ & $36.36 \pm 8.37$ & $6.34(2.21-18.24)$ & 0.001 \\
\cline { 2 - 6 }$-308 \mathrm{G} / \mathrm{A}$ & GA. \% & $21.62 \pm 6.77$ & $51.52 \pm 8.7$ & $0.26(0.09-0.73)$ & 0.001 \\
\cline { 2 - 6 } & AA. \% & $0 \pm 0$ & $12.12 \pm 5.68$ & $0.0(0.00-0.00)$ & 0.001 \\
\hline \multirow{2}{*}{ Alleles } & G-allele. \% & $89.19 \pm 3.61$ & $62.12 \pm 5.97$ & $5.03(12.07-12.21)$ & 0.000 \\
\cline { 2 - 6 } & A-allele. \% & $10.81 \pm 3.61$ & $37.88 \pm 5.97$ & $0.20(0.08-0.48)$ & 0.000 \\
\hline
\end{tabular}

Note: TNF- $\alpha$ is tumor necrosis factor alpha; OR is odd ratio, $95 \% \mathrm{CI}$ is confidence interval (CI) for OR, $p$ is significance of discrepancies; $\mathrm{AG}(1,2,3)$ and EA (I, II, III, IV) are degrees of attack gravity and endoscopic activity.

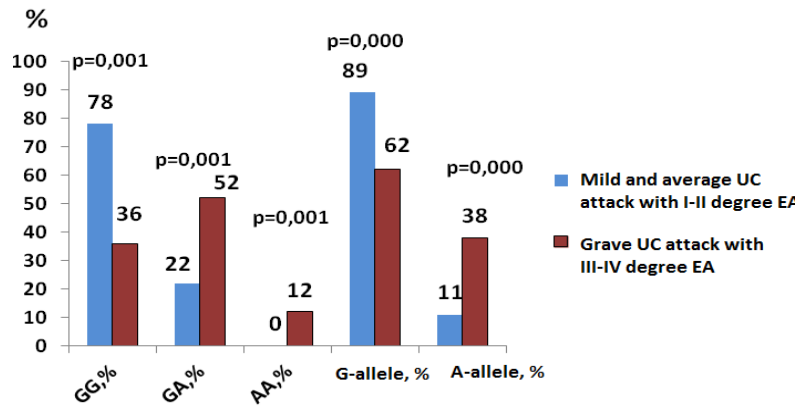

Figure 2. Frequency of allele variants occurrence in $T N F-\alpha-308 \mathrm{G} / \mathrm{A}(\mathrm{rs} 1800629)$ in patients with UC under various attack gravity and EA degree. Y-axis shows number of patients given in \%. $\mathrm{X}$-axis shows genotypes and alleles in $T N F-\alpha$ (rs1800629)

gene $T N F-\alpha$ polymorphism in $-308 \mathrm{G} / \mathrm{A}$ region had in UC development, we divided patients with UC into two sub-groups taking into account attack gravity (AG) and EA degree as per data obtained via sigmoidoscopy (SS) and fiber colonoscopy (FCS). The first sub-group $(\mathrm{n}=37)$ included patients suffering from UC with mild and average attack, rare recurrences, and with 1-2 degree EA. The second group $(n=33)$ was made up of patients with grave continuous UC with frequent recurrences and 3-4 degree EA.

TNF- $\alpha$ levels in patients with UC who had 3-4 degree EA were authentically higher than in patients with 1-2 degree EA $(p=0.0000)$ (Table 1). Assessment of TNF- $\alpha$ contents in blood serum in patients with UC can be quite informative for determining degree of EA and discussing adjustments to therapy.

We assessed frequency of allele variations in $T N F-\alpha-308 \mathrm{G} / \mathrm{A}$ (rs1800629) under different endoscopic activity and revealed that major allele $\mathrm{G}$ and allele pair GG significantly more frequently occurred among patients with mild or average attack and 1-2 degree EA than among those who had 3-4 degree EA and suffered from grave UC attack $(\chi 2=14.19 ; \mathrm{p}=0.000 ; \mathrm{OR}=6.34)$. Minor or mutant allele $\mathrm{A}$, on the contrary, significantly more frequently occurred among patients with 3-4 degree EA and grave UC attack, in $37.88 \% \quad\left(\chi^{2}=14.19 ; \mathrm{p}=0.000 ; \quad \mathrm{OR}=0.20\right)$ (Table 1, Figure 2).

Unfavorable homozygote AA was detected in $12.12 \%$ patients with UC and high EA and didn't occur in patients with low or average EA $(\chi 2=14.11 ; p=0.001 ; \quad O R=$ $=0.00$ ) (Table 1, Figure 2). Consequently, occurrence of mutant allele A and homozygote AA in $T N F-\alpha-308 \mathrm{G} / \mathrm{A}$ gene predict grave recurrent UC course with proneness to progress.

We examined dependences between examined qualitative signs with contingency tables (cross tabulation) among patients with 
UC and found an apparent correlation between polymorphism of promoter region $-308 \mathrm{G} / \mathrm{A}$ in $T N F-\alpha$ gene and an increase in production of the same TNF- $\alpha$ factor, attack gravity $\left(\mathrm{K}_{\mathrm{i}}=0.75 ; \mathrm{p}=0.000\right.$ and $\mathrm{K}_{\mathrm{i}}=0.84$; $\mathrm{p}=0000$ respectively), clinical and endoscopic activity indexes $\left(\mathrm{K}_{\mathrm{i}}=0.85 ; \mathrm{p}=0.000\right.$ and $\mathrm{K}_{\mathrm{i}}=0.78 ; \mathrm{p}=0.000$ respectively) and a length of damage areas in the colon as per endoscopy data $\left(\mathrm{K}_{\mathrm{i}}=0.89 ; \mathrm{p}=0.000\right)$. We also revealed a strong dependence on $\mathrm{C}$-reactive protein contents $\left(\mathrm{K}_{\mathrm{i}}=0.73 ; \mathrm{p}=0.000\right)$, blood leukocytes $\left(\mathrm{K}_{\mathrm{i}}=0.59 ; \mathrm{p}=0.000\right)$, sedimentation rate $\left(\mathrm{K}_{\mathrm{i}}=0.67 ; \mathrm{p}=0.000\right)$, and $\alpha_{1}, \alpha_{2}$ and $\gamma^{- \text {globulins }}\left(\mathrm{K}_{\mathrm{i}}=0.46 ; \mathrm{p}=0.017\right.$; $\left.\mathrm{K}_{\mathrm{i}}=0.72 ; \mathrm{p}=0.000 ; \mathrm{K}_{\mathrm{i}}=0.61 ; \mathrm{p}=0.000\right)$, which are conventional laboratory markers of an acute inflammation phase, and albumin contents in blood $\left(\mathrm{K}_{\mathrm{i}}=0.73 ; \mathrm{p}=0.000\right)$.

Therefore, this determined correlation between polymorphism of promoter region $308 \mathrm{G} / \mathrm{A}$ in $T N F-\alpha$ gene and increased TNF$\alpha$ expression in blood of patients with UC can make a contribution into immune-inflammatory syndrome activation among carriers; our results confirm data collected in other research [11-13]. The revealed correlation between polymorphism of this gene and UC attack gravity, EAI, blood parameters characteristic for an acute phase, as well as occurrence of mutant allele $\mathrm{A}$ and homozygote AA in patients with high EA degree and grave exacerbations, can indicate that there is a contribution made by $T N F-\alpha$ gene polymorphism into predisposition to unfavorable UC course. We assume this risk factor for grave UC course to be a significant one (homozygotes as per a normal allele predict milder disease course), OR 6.34 (CI 2.21-18.24).

We recommend to perform a preventive examination in order to detect a significant polymorph allele in $T N F-\alpha$ gene, $-308 \mathrm{G} / \mathrm{A}$ region (OR 5.03; CI 12.07-12.21); it will help create additional examination and therapeutic procedures for patients with UC as mutant allele occurrence results in 5 times higher risk of graver disease course.

Conclusion. We detected higher TNF- $\alpha$ contents in blood of patients with UC in its acute phase against the control group. Concentration of this cytokine was significantly higher in patients with grave disease course, frequent recurrences, and high EA degree; it can be applied to stratify UC attack gravity and to determine EA degree.

We examined distribution of genotypes and alleles in -308G/A region of TNF- $\alpha$ gene, rs1800629 position, among patients with UC and health people living in Perm region and revealed that GG genotype prevailed in them. We didn't detect statistically significant discrepancies in frequency of protective allele $G$ and minor allele A occurrence between the examined groups. Nevertheless, unfavorable homozygote AA significantly more frequently occurred among patients with UC than among healthy people. We can assume that if a person carriers this homozygote, he or she is genetically predisposed to UC.

Besides, as we assessed frequency of allele variations occurrence in $T N F-\alpha$ gene under different UC attack gravity and endoscopic activity, we detected mutant allele A and unfavorable homozygote AA to be correlated to grave and progressing UC course.

Consequently, a risk related to unfavorable UC course with frequent recurrence and progressing is associated with carrying mutant allele A of TNF- $\alpha-308 \mathrm{G} / \mathrm{A}$ gene. Given that, a genetic examination can be recommended when UC is diagnosed for the first time; this genetic examination should involve determining polymorphism of $T N F-\alpha-308 \mathrm{G} / \mathrm{A}$ gene in order to assess risks of unfavorable disease course and to work out individual therapeutic and prevention procedures.

Funding. The research has been accomplished as an assignment given by the state within the complex topic No. 115030310053.

Conflict of interests. the authors state there is no any conflict of interests. 


\section{References}

1. Ivashkin V.T., Shelygin Yu.A., Khalif I.L., Belousova E.A., Shifrin O.S., Abdulganieva D.I. [et al.]. Clinical guide of Russian association of gastroenterology and Russian association of coloproctology on diagnostics and treatment of ulcerative colitis. Koloproktologiya, 2017, vol. 59, no. 1, pp. 6-30 (in Russian).

2. Magro F., Gionchetti P., Eliakim R., Ardizzone S., Armuzzi A., Barreiro-de Acosta M. [et al.]. Third European Evidence-based Consensus on Diagnosis and Management of Ulcerative Colitis. Part 1: Definitions, Diagnosis, Extra-intestinal Manifestations, Pregnancy, Cancer Surveillance, Surgery, and Ileo-anal Pouch Disorders. Journal of Crohn's and Colitis, 2017, vol. 1, no. 6, pp. 649-670. DOI: $10.1093 /$ ecco-jec/jjx008

3. Tkachev A.V., Mkrtchyan L.S., Nikitina K.S., Volynskaya E.I. Inflammatory bowel disease: crossing of the problems. Prakticheskaya meditsina, 2012, vol. 58, no. 3, pp. 17-22 (in Russian).

4. Abdulkhakov S.R., Abdulkhakov R.A. Non-specific ulcerative colitis: up-to-date approaches to diagnostics and treatment. Vestnik sovremennoi klinicheskoi meditsiny, 2009, vol. 2, no. 1, pp. 32-41 (in Russian).

5. Kostić M., Djakovic L., Šujić R., Godman B., Janković S. Inflammatory Bowel Diseases (Crohn's Disease and Ulcerative Colitis): Cost of Treatment in Serbia and the Implications. Appl Health Econ Health Policy, 2017, vol. 15, no. 1, pp. 85-93. DOI: 10.1007/s40258-016-0272-z

6. Zheleznikova. G.F. Cytokines as predictors of infection course and outcome. Tsitokiny $i$ vospalenie, 2009, vol. 8, no. 1, pp. 10-7 (in Russian).

7. Lee M.J., Lee J., Choi J.W., Lee C., Sim J.H., Cho C.H. [et al.]. Interleukin-6 Induces S100A9 Expression in Colonic Epithelial Cells through STAT3 Activation in Experimental Ulcerative Colitis. PLoS One, 2012, vol. 7, no. 9, pp. e38801. DOI: 10.1371/journal.pone.0038801

8. Arora Z., Shen B. Biological therapy for ulcerative colitis. Gastroenterol Rep (Oxf), 2015, vol. 3, no. 2, pp. 103-109. DOI: 10.1093/gastro/gou070

9. Wang Y., Mao J. Expression of matrix metalloproteinase-1 and tumor necrosis factor- $\alpha$ in ulcerative colitis. World J. Gastroenterol, 2007, vol. 44, no. 13, pp. 5926-5932.

10. Cuković-Cavka S., Vucelić B., Urek M.C., Brinar M., Turk N. The role of anti-TNF therapy in ulcerative colitis. Acta. Med. Croatica, 2013, vol. 67, no. 2, pp. 171-177.

11. Al-Meghaiseeb E., Al-Robayan A., Al-Otaibi M., Arfin M., Al-Asmari A. Association of tumor necrosis factor- $\alpha$ and $-\beta$ gene polymorphisms in inflammatory bowel disease. J. Inflamm. Res., 2016, no. 9, pp. 133-140. DOI: 10.2147/JIR.S101225

12. Stepina E.A., Khlynova O.V., Tuev A.V. Diagnostic and prognostic value of endothelial dysfunction markers in patients with ulcerative colitis. Kazanskii meditsinskii zhurnal, 2016, vol. 97, no. 2, pp. 187-191 (in Russian).

13. Simbirtsev. A.S., Gromova A.Yu. Functional gene polymorphisms of the molecules regulating inflammation. Tsitokiny $i$ vospalenie, 2005, vol. 4, no. 1, pp. 1-10 (in Russian).

14. McGovern D.P., Gardet A., Törkvist L., Goyette P., Essers J., Taylor K.D. [et al.]. Genome-wide association identifies multiple ulcerative colitis susceptibility loci. Nat Genet, 2010, vol. 42, no. 4, pp. 332-337.

15. Gök İ., Uçar F., Ozgur O. Inflammatory cytokine gene polymorphism profiles in Turkish patients with ulcerative colitis. Med. Glas (Zenica), 2015, vol. 12, no. 1, pp. 33-39.

16. Song Y., Wu K.C., Zhang L., Hao Z.M., Li H.T., Zhang L.X. [et al.]. Correlation between a gene polymorphism of tumor necrosis factor and inflammatory bowel disease. Chin. J. Dig. Dis., 2005, vol. 6, no. 4, pp. 170-174.

17. Wang F., Wang M., Chen W., Hu F., Li D., Ren J. [et al.]. Relationship between the polymorphism of tumor necrosis factor- $\alpha-308 \mathrm{G}>\mathrm{A}$ and susceptibility to inflammatory bowel diseases and colorectal cancer: a meta-analysis. Eur. J. Hum. Genet, 2011, vol. 19, no. 4, pp. 432-437. 
18. Valuiskikh E.Yu., Svetlova I.O., Kurilovich S.A., Osipenko M.F., Maksimov V.N., Voevoda M.I. Clinical and genetic aspects of inflammatory bowel diseases. Rossiiskii zhurnal gastroenterologii, gepatologii i koloproktologii, 2008, vol. 18, no. 6, pp. 68-74 (in Russian).

19. Bonyadi M., Abdolmohammadi R., Jahanafrooz Z., Somy M.H., Khoshbaten M. TNF-alpha gene polymorphisms in Iranian Azari Turkish patients with inflammatory bowel diseases. Saudi. J. Gastroenterol, 2014, vol. 20, no. 2, pp. 108-12. DOI: 10.4103/1319-3767.129475

Tretyakova Yu.I., Shchekotova A.P., Bulatova I.A., Krivtsov A.V. Unfavorable clinic course of ulcerative colitis: risk assessment with determining gene polymorphism of tumor necrosis factor alpha. Health Risk Analysis, 2019, no. 2, pp. 138-144. DOI: 10.21668/health.risk/2019.2.16.eng

Received: 22.11.2018

Accepted: 24.05.2019

Published: 30.06.2019 